\title{
PENGARUH PERSEPSI PESERTA DIDIK TENTANG KOMPETENSI KEPRIBADIAN GURU TERHADAP MOTIVASI BELAJAR SISWA SMK
}

\author{
Mohamad J. E. Sulaki ${ }^{1}$, Aam Hamdani' ${ }^{2}$, Ridwan A. M. Noor ${ }^{3}$ \\ Universitas Pendidikan Indonesia \\ J1. Dr. Setiabudhi No. 207 Bandung 40154 \\ m.jomka@student.upi.edu
}

\begin{abstract}
ABSTRAK
Penelitian ini bertujuan untuk mengetahui pengaruh persepsi peserta didik tentang kompetensi kepribadian guru terhadap motivasi belajar peserta didik di SMK Negeri 8 Bandung. Metode yang digunakan dalam penelitian ini yaitu metode ex post facto. Instrumen yang digunakan adalah kuesioner yang jumlah respondennya sebanyak 125 peserta didik yang diambil menggunakan teknik purposive sampling. Teknik analisis data menggunakan uji regresi sederhana. Hasil penelitian menunjukkan bahwa tingkat persepsi tentang kepribadian guru masuk dalam kategori rendah dengan persentase sebesar $36 \%$. Motivasi peserta didik berada dalam kategori sedang dengan persentase $66,4 \%$. Pengaruh persepsi peserta didik tentang kepribadian guru terhadap motivasi belajar peserta didik menunjukkan nilai positif dan signifikan dengan nilai koefisien determinasi yang menunjukkan besar hubungan antara keduanya sebesar 13,6 \%. Kesimpulan yaitu bahwa persepsi tentang kompetensi kepribadian guru berpengaruh terhadap motivasi belajar siswa.
\end{abstract}

Kata kunci: persepsi siswa, kompetensi kepribadian, motivasi belajar

\section{PENDAHULUAN}

Pendidikan merupakan bagian terpenting dari proses pembangunan nasional, selain itu pendidikan juga merupakan penentu ekonomi dari negara (Hardianto, 2017). Pernyataan tersebut secara tidak langsung mengisyaratkan bahwa tinggi rendahnya tingkat perekonomian suatu negara dipengaruhi oleh bagaimana pendidikan negara tersebut berlangsung. Jika sektor pendidikan suatu negara berlangsung baik, maka negara tersebut akan maju, begitupun sebaliknya.

Anggapan tentang pentingnya pendidikan tersebut berlaku untuk semua negara, termasuk Indonesia. Salah satu upaya yang dilakukan untuk membangun Indonesia menjadi sebuah negara yang maju adalah perlunya memiliki sebuah sistem pendidikan yang baik. Penjelasan tersebut tercermin dalam Undang-Undang Nomor 20 Tahun 2003 tentang sistem pendidikan nasional sebagai berikut. Pendidikan adalah usaha sadar dan terencana untuk mewujudkan suasana belajar dan proses pembelajaran agar peserta didik secara aktif mengembangkan potensi dirinya untuk memiliki kekuatan spiritual keagamaan, pengendalian diri, kepribadian, kecerdasan, akhlak mulia, serta keterampilan yang diperlukan dirinya, masyarakat, bangsa, dan negara (Dimyati dan Mudjiono, 2009).

\footnotetext{
${ }^{1}$ Mahasiswa Departemen Pendidikan Teknik Mesin FPTK UPI

2 Dosen Departemen Pendidikan Teknik Mesin FPTK UPI

${ }^{3}$ Dosen Departemen Pendidikan Teknik Mesin FPTK UPI
} 
Tujuan proses pendidikan adalah peserta didik tidak hanya dituntut untuk memiliki keterampilan yang diperlukan oleh dirinya sebagai individu, tetapi juga diharuskan memiliki keterampilan yang diperlukan oleh masyarakat, bangsa, dan negara. Salah satu upaya untuk mewujudkan tujuan pendidikan nasional yaitu pemerintah membuat Peraturan Pemerintah Nomor 19 Tahun 2005 tentang Standar Nasional Pendidikan. Isi Peraturan Pemerintah tersebut membahas mengenai kriteria minimal sistem pendidikan yang berlangsung di wilayah hukum Indonesia. Kriteria-kriteria tersebut menjadi standar sistem pendidikan yang terdiri dari delapan standar yaitu: (1) standar isi, (2) standar proses, (3) standar kompetensi lulusan, (4) standar pendidik dan tenaga kependidikan, (5) standar sarana dan prasarana, (6) standar pengelolaan, (7) standar pembiayaan, dan (8) standar penilaian pendidikan. Delapan butir standar tersebut harus diimplementasikan sebagaimana mestinya untuk dapat mewujudkan sistem pendidikan di Indonesia yang baik dan dapat mencapai tujuan. Terdapat ketimpangan satu saja standar pada implementasinya, sehingga proses pendidikan tidak akan berjalan dengan baik dalam mencapai tujuan yang diharapkan.

Pendidik merupakan subjek yang berhubungan langsung dengan peserta didik dalam proses belajar mengajar. Tersampaikan atau tidaknya materi pelajaran kepada peserta didik sangat bergantung dari bagaimana sikap seorang pendidik dalam proses belajar mengajar, baik di dalam kelas maupun di luar kelas (Jahangiri, 2016). Guru adalah pendidik profesional dengan tugas utama mendidik, mengajar, membimbing, mengarahkan, melatih, menilai dan mengevaluasi peserta didik pada pendidikan anak usia dini jalur pendidikan formal, pendidikan dasar dan pendidikan menengah (Mulyasa, 2007).

Tugas guru sebagai pendidik profesional yang tercantum dalam Undang-Undang tersebut harus dilaksanakan seoptimal mungkin agar tujuan kegiatan belajar mengajar dapat tercapai (Mulyasa, 2008). Hal tersebut menjadi sebuah catatan penting bahwa tidak sembarang orang dapat menjadi guru. Guru wajib memiliki kualifikasi akademik, kompetensi, sertifikat pendidik, sehat jasmani dan rohani, serta memiliki kemampuan untuk mewujudkan tujuan pendidikan nasional (Kompri, 2015).

Kompetensi adalah seperangkat sikap, pengetahuan, dan keterampilan yang harus dimiliki, dihayati, dan dikuasai oleh peserta didik setelah mempelajari suatu muatan pembelajaran, menamatkan suatu program, atau menyelesaikan satuan pendidikan tertentu. Hal tersebut dengan jelas menunjukkan bahwa kompetensi yang harus dimiliki seorang guru meliputi kompetensi pedagogik, kompetensi kepribadian, kompetensi sosial, dan kompetensi profesional yang diperoleh melalui pendidikan profesi (Nursyamsi, 2014). 
Kompetensi pertama yang harus dimiliki oleh seorang guru adalah kompetensi pedagogik. Kompetensi ini adalah kemampuan guru dalam pengelolaan pembelajaran peserta didik yang sekurang-kurangnya meliputi pemahaman wawasan atau landasan kependidikan, pemahaman terhadap peserta didik, pengembangan kurikulum atau silabus, perancangan pembelajaran, pelaksanaan pembelajaran yang mendidik dan dialogis, pemanfaatan teknologi pembelajaran, evaluasi hasil belajar dan pengembangan peserta didik untuk mengaktualisasikan berbagai potensi yang dimilikinya. Selain kemampuan mengelola pembelajaran, kompetensi kepribadian juga menjadi poin penting yang wajib dimiliki oleh guru. Cakupan kompetensi kepribadian seorang guru adalah beriman dan bertakwa, berakhlak mulia, arif dan bijaksana, demokratis, mantap, berwibawa, stabil, dewasa, jujur, sportif, menjadi teladan bagi peserta didik dan masyarakat, secara obyektif mengevaluasi kinerja sendiri, dan mengembangkan diri secara mandiri dan berkelanjutan (Susetyowati dan Susena, 2013).

Kepribadian guru yang baik harus disertai sikap profesionalitas seorang guru dalam proses belajar mengajar. Kompetensi profesional adalah kemampuan guru dalam menguasai pengetahuan bidang ilmu pengetahuan, teknologi, dan/atau seni dan budaya yang diampunya. Sekurang-kurangnya meliputi penguasaan materi pelajaran secara luas dan mendalam sesuai dengan standar isi program satuan pendidikan, mata pelajaran, dan atau kelompok mata pelajaran yang akan diampu serta konsep dan metode disiplin keilmuan, teknologi, serta seni yang relevan. Secara konseptual menaungi atau koheren dengan program satuan pendidikan, mata pelajaran, dan/atau kelompok mata pelajaran yang akan diampu. Sehingga seorang guru yang profesional dapat memberikan transfer ilmu yang lebih baik terhadap muridnya.

Penguasaan materi yang baik oleh guru harus dibarengi dengan komunikasi yang baik pula. Kemampuan komunikasi yang dimiliki guru tidak hanya ketika berperan di lingkungan sekolah, tetapi juga saat berada di lingkungan sosial. Kompetensi sosial adalah kemampuan guru sebagai bagian dari masyarakat yang sekurang-kurangnya meliputi kompetensi untuk berkomunikasi lisan, tulisan, dan/atau isyarat secara santun, menggunakan teknologi komunikasi dan informasi secara fungsional. Guru harus mudah bergaul secara efektif dengan peserta didik, sesama pendidik, tenaga kependidikan, pimpinan satuan pendidikan, orang tua atau wali peserta didik. Bergaul secara santun dengan masyarakat sekitar dengan mengindahkan norma serta sistem nilai yang berlaku dan menerapkan prinsip persaudaraan sejati dan semangat kebersamaan (Yusuf dan Sugandhi, 2011). 
Masalah yang masih terlihat adalah masih adanya guru yang kurang disiplin. Hal ini terlihat dari jam masuk dan keluar seorang guru dalam kegiatan pembelajaran yang terkadang tidak tepat waktu. Selain itu, adapula guru yang tidak hadir di kelas dan tidak memberikan tugas sehingga peserta didik tidak meakukan proses pembelajaran sama sekali. Seorang guru yang melakukan tindakan ketidak disiplinan waktu akan berdampak kepada semangat siswa untuk belajar, karena semua yang dilakukan guru merupakan contoh bagi peserta didik (Yusuf dan Nurihsan, 2008).

Penanganan peserta didik di kelas ketika pembelajaran berlangsungpun masih ditemukannya guru yang menyamakan antara peserta didik yang rajin dan malas dalam proses pembelajaran. Perilaku ini menunjukkan bahwa guru tersebut tidak menerapkan proses pembelajaran yang adil bagi setiap peserta didik di dalam kelasnya. Hal ini menyebabkan peserta didik yang malas tidak mendapatkan perhatian lebih dari guru dan memungkinkan tidak tercapainya tujuan pembelajaran (Suharsaputra, 2013).

Persoalan tersebut berkaitan erat dengan peserta didik, sebab mereka merupakan objek dalam kegiatan belajar mengajar. Peserta didik secara langsung melihat semua hal yang dilakukan oleh gurunya baik di kelas, maupun di lingkungan sekolah. Hal itu menyebabkan peserta didik mendapatkan contoh yang tidak baik dari seorang guru yang dimana seharusnya menjadi teladan bagi mereka. Pembicaraan guru, perilaku guru, sikap guru dalam menilai sesuatu, kemampuan guru dalam memecahkan masalah, kedisiplinan guru, kepemimpinan guru, tanggung jawab guru, kejujuran guru, kreativitas guru, inisiatif guru, dan bahkan cara guru berpakaian sekalipun, disadari atau tidak, akan menjadi contoh bagi peserta didik (Fudyartanta, 2012).

Salah satu jenis persepsi yaitu persepsi yang dipelajari, persepsi yang dipelajari merupakan persepsi yang terbentuk karena individu mempelajari sesuatu dari lingkungan sekitar. Persepsi yang dipelajari berbentuk fikiran, ide atau gagasan dan keyakinan yang kita pelajari dari orang lain (Rochman dan Gunawan, 2011)). Jadi reaksi setiap individu berbasis pada persepsi yang dia telah pelajari, seperti anak-anak yang mengikuti perangai dan kepribadian orang tua mereka. Persepsi tentang suatu hal akan mempengaruhi tindakan yang akan dilakukan terhadap hal tersebut, termasuk persepsi siswa terhadap gurunya yang akan mempengaruhi proses belajar mereka yang salah satunya juga dipengaruhi oleh motivasi mereka dalam belajar.

Fenomena peserta didik yang menunjukkan tanda-tanda kurangnya motivasi dalam belajar seringkali ditemui di sekolah. Hasil observasi masih kurangnya motivasi peserta didik ditunjukkan dengan tanda-tanda diantaranya: 1) peserta didik meminta pelajaran 
diakhiri sebelum waktunya, 2) peserta didik tidak mengerjakan tugas yang diberikan, 3) peserta didik tidak mengikuti pelajaran/bolos, 4) peserta didik melakukan aktivitas yang tidak berhubungan dengan proses kegiatan belajar mengajar saat proses pembelajaran berlangsung, 5) peserta didik datang terlambat, dan 6) tidak berpartisipasi aktif dalam pembelajaran (Rechman, 2014).

\section{METODE PENELITIAN}

Metode penelitian yang penulis gunakan di dalam penelitian ini adalah dengan menggunakan metode ex post facto. Variabel bebas dari penelitian ini adalah persepsi peserta didik tentang kompetensi kepribadian guru, sedangkan variabel terikatnya adalah motivasi belajar peserta didik. Penelitian ini bertujuan untuk mengetahui pengaruh variabel bebas dengan variabel terikat.

Responden yang terlibat dalam penelitian ini adalah 125 orang. Instrumen yang digunakan adalah angket atau kuesioner jenis tertutup langsung dan tidak langsung. Kuesioner langsung digunakan untuk mengukur mengenai motivasi belajar peserta didik, sedangkan kuesioner tidak langsung digunakan untuk mengukur tentang kompetensi kepribadian guru dengan menggunakan skala Likert dengan empat alternatif jawaban. Uji validitas instrumen melalui validitas konstruk dan isi. Menguji validitas konstruk dengan digunakan pendapat dari ahli (judgement experts) dan menguji validitas isi melalui uji statistik. Analisis data digunakan uji regresi sederhana untuk mengetahui keadaan variabel terikat terhadap satu variabel bebas. Koefisien regresi berfungsi sebagai alat untuk membuktikan hubungan antara variabel bebas dan terikat. Pengujian koefisien determinasi atau koefisien penentu dilakukan untuk mengetahui besarnya pengaruh variabel bebas terhadap variabel terikat.

\section{HASIL PENELITIAN}

Skor rata-rata indikator kompetensi kepribadian guru ditunjukkan pada Tabel 1. Dimana isinya menyajikan skor rata-rata dari masing masing indikator yang digunakan untuk mengukur kompetensi kepribadian guru. Skor rata-rata motivasi peserta didik ditunjukkan pada Tabel 2. Dimana isinya menyajikan skor rata-rata dari masing masing indikator yang digunakan untuk mengukur motivasi peserta didik. 
Tabel 1. Skor rata-rata kompetensi kepribadian guru

\begin{tabular}{clc}
\hline No & \multicolumn{1}{c}{ Indikator } & Skor Rata-rata \\
\hline 1 & Berakhlak mulia & 3,18 \\
2 & Disiplin & 3,10 \\
3 & Arif & 3,39 \\
4 & Demokratis & 3,27 \\
5 & Mantap & 3,16 \\
6 & Berwibawa & 3,06 \\
7 & Stabil & 2,92 \\
8 & Dewasa & 2,98 \\
9 & Jujur dan Adil & 3,03 \\
10 & Menjadi teladan & 3,15 \\
11 & Percaya Diri & 3,05 \\
& $\quad$ Rata-Rata & 3,12
\end{tabular}

Tabel 2. Skor rata-rata motivasi peserta didik

\begin{tabular}{clc}
\hline No & \multicolumn{1}{c}{ Indikator } & Skor Rata-rata \\
\hline 1 & Tekun menghadapi tugas & 2,88 \\
2 & Ulet menghadapi kesulitan & 2,69 \\
3 & Menunjukkan minat terhadap mata pelajaran & 3,19 \\
4 & Dapat mempertahankan pendapatnya & 2,82 \\
5 & Senang mencari dan memecahkan soal-soal & 2,42 \\
6 & Lebih senang bekerja mandiri & 2,69 \\
7 & Cepat bosan pada tugas-tugas yang rutin & 2,97 \\
& $\quad$ Rata-rata & 2,81 \\
\hline
\end{tabular}

\section{PEMBAHASAN}

Skor tertinggi berada pada indikator arif. Pengertian arif disini yaitu guru menunjukkan keterbukaan dalam berpikir dan bertindak (Barnawi dan Arifin, 2012). Skor terendah berada pada indikator stabil. Hal ini menunjukkan kepribadian guru dalam bertindak kurang sesuai dengan norma hukum, norma sosial (bangga sebagai guru), dan kurang memiliki konsistensi dalam bertindak sesuai dengan norma (Anwar, 2011). Selain itu, guru dalam mengekspresikan emosi kurang memperhatikan prinsip stabilitas yang mencerminkan dirinya sebagai pendidik, dimana meluapkan rasa senang, sedih, marah dan sejenisnya dianggap berlebihan dan tidak pada tempatnya (Cahyani, 2014).

Skor rata-rata tertinggi berada pada indikator peserta didik menunjukkan minat terhadap mata pelajaran. Hal ini menunjukkan bahwa peserta didik sebenarnya memiliki minat terhadap mata pelajaran yang diberikan di sekolah, walaupun tidak semua peserta didik. Segala sesuatu yang menarik minat orang lain belum tentu menarik minat yang lain 
selama sesuatu itu tidak bersentuhan dengan kebutuhannya (Djamarah, 2011). Tidak mengerjakan soal latihan atau tugas yang diberikan guru bisa saja terjadi dalam sebuah pemebelajaran. Namun sebenarnya peserta didik telah memiliki minat terhadap pelajaran tersebut. Ada faktor lain di luar diri peserta didik yang bisa membuat peserta didik tidak mengerjakan tugas yang diberikan, misalnya proses pembelajaran yang kurang menarik perhatian peserta didik (Rochman Gunawan, 2011). Skor rata-rata terendah berada pada indikator senang mencari dan memecahkan soal-soal. Hal ini menunjukkan bahwa peserta didik kurang memiliki perhatian terhadap mencari dan memecahkan soal-soal dan bisa saja terjadi karena terbatasnya sumber belajar yang dimiliki oleh peserta didik maupun fasilitas perpustakaan yang ada di sekolah (Kwon, 2016).

Uji normalitas untuk variabel kompetensi kepribadian guru, menunjukkan kedua variabel berdistribusi normal. Hasil uji linearitas diperoleh ada hubungan yang linier antara kedua variabel tersebut. Uji hipotesis yang digunakan yaitu analisis regresi sederhana untuk menghitung besar pengaruh variabel kepribadian guru terhadap motivasi belajar peserta didik. Hasil persamaan regresi $\mathrm{n}$ dalam bentuk persamaan regresi sesuai dengan rumus $\hat{Y}=$ $34,483+0,253 \mathrm{X}$. Persamaan regresi sederhana dapat dinyatakan bahwa jika variabel kepribadian guru dianggap nol, maka motivasi belajar memiliki nilai 34,5 satuan. Angka 0,25 merupakan nilai koefisien regresi untuk variabel kepribadian guru. Persamaan regresi sederhana dapat dinyatakan bahwa jika terjadi kenaikan pada variabel kepribadian guru, maka akan menaikkan motivasi belajar peserta didik (Darojah, 2016).

Pengujian hipotesis dilakukan menggunakan analisis regresi sederhana satu prediktor. Hasil uji hipotesis menyatakan bahwa secara positif dan signifikan terdapat pengaruh antara persepsi peserta didik tentang kompetensi kepribadian guru terhadap motivasi belajar peserta didik (Jasmi and Hin, 2014). Hasil analisis menunjukkan bahwa korelasi antar dua variabel adalah sebesar 0,368. Hasil perhitungan koefisien determinasi menunjukkan bahwa pengaruh persepsi tentang kompetensi kepribadian guru terhadap motivasi belajar peserta didik termasuk pada kategori rendah (Lennon, 2012).

Kondisi tersebut merupakan bahan bagi guru untuk evaluasi diri mengenai kompetensi kepribadian yang dimiliki. Sehingga ketika merasa dirinya kurang berkompeten dari segi kepribadian, bisa melakukan tindakan yang dapat meningkatkan kompetensinya dengan cara mengikuti pelatihan atau dengan cara berdiskusi dengan sesama guru (Garcia, 2011). Sekolah, hendaknya melakukan pendekatan yang bertujuan untuk mengetahui kompetensi guru-guru yang berada dibawah naungannya secara berkala. Kompetensi yang dimiliki oleh guru bisa diketahui dan bisa dilakukan upaya peningkatan. Jika ternyata hasilnya 
menunjukkan tingkat kompetensi yang rendah, maka dapat dilakukan pelatihan di dalam sekolah maupun mengirimkan guru-gurunya untuk melaksanakan pelatihan terkait (Milfayetty, 2009).

Hasil penelitian ini bisa memberikan gambaran mengenai kompetensi kepribadian guru dan motivasi belajar peserta didik. Pengaruh antara kompetensi kepribadian guru terhadap motivasi belajar peserta didik di SMK Negeri 8 Bandung sehingga bisa menjadi acuan untuk tindakan yang akan dilakukan sekolah terhadap peserta didik maupun guru (Dislen, 2013).

\section{KESIMPULAN}

Kesimpulan penelitian ini, yaitu kompetensi pribadi guru berpengaruh terhadap motivasi belajar peserta didik. Persepsi peserta didik memiliki pengaruh yang rendah terhadap kompetensi kepribadian guru dan motivasi belajar peserta didik.

\section{REFERENSI}

Anwar, S. (2011). Studi Realitas tentang Kompetensi Kepribadian Guru Pendidikan Agama Islam Sekolah Menengah Atas di Kabupaten Bandung Barat. Jurnal Pendidikan Agama Islam-Ta'lim. 9(2), 145-159.

Barnawi dan Arifin, M. (2012). Etika dan Profesi Kependidikan. Jogjakarta: Ar-Ruzz Media.

Cahyani, F. D. (2014). Hubungan antara Persepsi Siswa Terhadap Kompetensi Pedagogik, Kompetensi Kepribadian, dan Kompetensi Sosial Guru dengan Motivasi Berprestasi Siswa Akselerasi di SMA Negeri I Gresik. Jurnal Psikologi Pendidikan dan Perkembangan. 3(2), 77-88.

Darojah, N. R. (2016). Analisis Pengaruh Kompetensi Kepribadian Guru dengan Motivasi Belajar sebagai Variabel Intervening terhadap Prestasi Belajar Siswa Kelas X Administrasi Perkantoran. Jurnal Pendidikan Manajemen Perkantoran. 1(1), 115125.

Dimyati dan Mudjiono. (2009). Belajar dan Pembelajaran. Jakarta: Rineka Cipta.

Dislen, G. (2013). The Reasons of Lack of Motivation from The Students' and Teachers' Voices. ASOS Journal. 1(1). 35-45.

Djamarah, S. B. (2011). Psikologi Belajar. Jakarta: Rineka Cipta.

Fudyartanta, K. (2012). Psikologi Kepribadian: Paradigma Filosofis, Tipologis, Psikodinamik dan Organismik-Holistik. Yogyakarta: Pustaka Pelajar. 
Garcia, P. (2011). Impact of Teacher Personality Styles on Academic Excellence of Secondary Students. National Forum of Teacher Education Journal. 21(3), 1-8.

Hardianto. (2017). Pengaruh Ekonomi Terhadap Pendidikan dan Peran Pendidikan Membangun Ekonomi. HIKMAH: Jurnal Pendidikan Islam. 6(1), 1-17.

Jahangiri, M. (2016). Teacher' Personality and Students' Learning Motivation. Academic Journal of Psychological Studies. 5(3), 208-214.

Jasmi, A. N. and Hin, L. C. (2014). Student-Teacher Relationship and Student Academic Motivation. Journal of Interdisciplinary Research in Education (JIRE). 4(1), 75-82.

Kompri. (2015). Motivasi Pembelajaran Perspektif Guru dan Siswa. Bandung: Rosdakarya.

Kwon, H. (2016). Middle School Students' Motivation for Learning Technology in South Korea. ISER, Eurasia Journal of Mathematics, Science \& Technology Education. 12(4). 1033-1046.

Lennon, S. M. (2012). Teacher Personality and Leadership: Exploring Potential Differences in Teaching Styles and Experience. International Journal of Humanities and Social Science. 2(14), 38-45.

Mahadi, T. S. T. (2012). Motivation, Its Types, and Its Impacts in Language Learning. International Journal of Business and Social Science. Vol. 3 No. 24, 230-235.

Milfayetty, S. (2009). Hubungan Kompetensi Kepribadjian Guru dan Reinforcement dengan Motivasi Belajar Siswa di SMA Negeri 11 Medan. Jurnal Analitik. 1(1), 1-11.

Mulyasa, E. (2007). Menjadi Guru Profesional: Menciptakan Pembelajaran Kreatif dan Menyenangkan. Bandung: PT Remaja Rosdakarya.

Mulyasa, E. (2008). Standar Kompetensi dan Sertifikasi Guru. Bandung: PT Remaja Rosdakarya.

Nursyamsi. (2014). Pengembangan Kepribadian Guru. Jurnal Al-Ta'lim. 21(1), 32-41.

Rechman, A. (2014). The Role of Motivation in Learning English Language for Pakistani Learners. International Journal of Humanities and Social Science. 4(1), 254-258.

Rochman, C. dan Gunawan, H. (2011). Pengembangan Kompetensi Kepribadian Guru: Menjadi Guru yang Dicintai dan Diteladani oleh Siswa. Bandung: Nuansa Cendikia.

Suharsaputra, U. (2013). Menjadi Guru Berkarakter. Bandung: PT Refika Aditama.

Susetyowati, T. dan Susena. (2013). Hubungan Kompetensi Kepribadian Guru Dengan Prestasi Belajar Siswa di SMP Muhammadiyah 2 Kalasan. Jurnal Citizenship. 3(1), $1-9$. 
Yusuf, L. N., S. dan Sugandhi, N. M. (2011). Perkembangan Peserta Didik : Mata Kuliah Dasar Profesi (MKDP) Bagi Para Mahasiswa Calon Guru di Lembaga Pendidikan Tenaga Kependidikan (LPTK). Jakarta: Rajawali Pers.

Yusuf, L. N., S. dan Nurihsan, A. J. (2008). Teori Kepribadian. Bandung: Rosdakarya. 